\title{
NPC1L1 wt Allele
}

National Cancer Institute

\section{Source}

National Cancer Institute. NPC1L1 wt Allele. NCI Thesaurus. Code C74461.

Human NPC1L1 wild-type allele is located in the vicinity of 7p13 and is approximately 29 $\mathrm{kb}$ in length. This allele, which encodes Niemann-Pick C1-like protein 1, is involved in the mediation of cholesterol and lipid transport. Mutations in the gene may be associated with ezetimibe treatment resistance. 